\title{
PENGEMBANGAN BAHAN AJAR ILMU PENGETAHUAN SOSIAL BERBASIS KURIKULUM 2013 PENDIDIKAN KHUSUS YANG MENGINTEGRASIKAN NILAI KARAKTER SISWA TUNARUNGU DI SDLB
}

\author{
Latifatur Rochmah \\ SLB Pembina Tingkat Nasional Bagian C Malang \\ Email: latifakahar@gmail.com
}

\begin{abstract}
Abstrak
Bahan ajar Ilmu Pengetahuan Sosial berbasis Kurikulum 2013 yang mengintegrasikan nilai-nilai karakter siswa tunarungu di SDLB. Penelitian ini adalah penelitian pengembangan. Penelitian dirancang dengan menggunakan model pengembangan 4-D yang terdiri dari empat tahapan, yaitu tahap pendefinisian, tahap perancangan, tahap pengembangan, dan tahap penyebarluasan. Subyek penelitian adalah guru kelas dan peserta didik tunarungu di kelas 4 dan 5 SDLB di SLB Pembina Tingkat Nasional Bagian C Malang. Pengumpulan data dilakukan melalui observasi, angket, dan tes. Berdasarkan hasil di lapangan bahan ajar yang dihasilkan telah memenuhi kriteria keefektifan.
\end{abstract}

Kata kunci : Bahan ajar Ilmu Pengetahuan Sosial, Kurikulum 2013 Pendidikan Khusus, Pendidikan Karakter

\section{Abstract}

Curriculum 2013 based Social Studies teaching material that integrates the values of deaf student characters in SDLB. This research is a research development. The study was designed using a 4-D development model consisting of four stages, namely preliminary design, design design, development, and dissemination. The subjects of the study were classroom teachers and deaf students in grades 4 and 5 SDLB in SLB Pembina Tingkat Nasional Bagian C Malang. Data collection is done through collection, questionnaires, and tests. Based on the results in the field the teaching materials produced have met the effectiveness criteria.

Keyword : Social Teaching Material, 2013 Special Education Curriculum, Character Building

\section{PENDAHULUAN}

Kebijakan Kementerian pendidikan dan Kebudayan dalam mengimplementasikan Kurikulum 2013 untuk pendidikan formal telah dimulai sejak tahun ajaran 2013/2014 dengan pola terbatas dan bertahap. Sementara itu, pengimplementasi kurikulum untuk Pendidikan Khusus atau Sekolah Luar Biasa dimulai satu tahun setelahnya yaitu pada tahun ajaran 2014/2015 untuk semua satuan pendidikan (SDLB,SMPLB, dan SMALB), juga dilakukan dengan pola secara bertahap. Dalam rancangan
Kurikulum 2013 Pendidikan Khusus terdapat perubahan yang signifikan jika dibandingkan dengan kurikulum sebelumnya. Diantaranya dalam hal manajemen sekolah, pembelajarann dan penilaian peserta didik. Kurikulum 2013 tidak hanya menitik beratkan pada keterampilan dan pengetahuan yang bermuara pada kreatifitas dan kompetensi peserta didik, tetapi juga menitikberatkan pada menanamkan moralitas dan budi pekerti ke dalam diri mereka yang berbuah pada sikap akhlak yang baik di tengah-tengah masyarakat nantinya. Dalam hal ini pembentukan sikap dan karakter 
ditempatkan sejajar dengan kemampuan kognitif dan psikomotor peserta didik.

Nilai karakter merupakan aspek utama dalam kehidupan abad ke-21 yang dikembangkan melalui proses pembelajaran. Drake dan Burns (2014) menyusun kerangka pengetahuan, keterampilan, dan sikap dalam bentuk piramida dengan menempatkan sikap/nilai-nilai pada posisi puncak dan pengetahuan sebagai basisnya. Sikap/nilai-nilai menjadi jembatan penghubung antara pengetahuan dan keterampilan. Kerangka ini dapat menjadikan sikap/nilai karakter merupakan aspek utama yang perlu ditumbuhkan di ruang kelas dan menjadi bagian yang terintegrasi dalam proses pembelajaran

Hasil penelitian menunjukkan bahwa nilai-nilai pendidikan karakter yang ditanamkan di sekolah memiliki memiliki dampak terhadap prestasi akademik, kepribadian dan sosial peserta didik. Studi yang dilakukan Larson (2009) menunjukkan bahwa penanaman nilai karakter melalui sekolah berdampak terhadap kepedulian, tanggung jawab, dan sikap hormat peserta didik terhadap orang lain. Dalam penelitian ini, terungkap bahwa pendidikan karakter memberikan pengaruh yang cukup signifikan terhadap perubahan perilaku peserta didik tunarungu dalam bersosialisasi.

Bahan ajar merupakan media yang tepat untuk mengintegrasikan pendidikan karakter. Sesuai dengan tuntutan Kurikulum 2013, nilai-nilai dan karakter bangas merupakan bagian yang integraldalam setiap kegiatan belajar. Nilai karakter bukan merupakan pelajaran tersendiri, tetapi menyatu dalam proses pembelajaran termasuk bahan ajar yang digunakan. Lickona (2008) dan Nucci \& Narvaez (2008) menunjukkan model integrasi pendidikan karakter dalam pembelajaran melalui intrakurikuler dan ekstrakurikuler. Integrasi melalui kegiatan intrakurikuler dapat dilakukan melalui kegiatan strategi pembelajaran, bahan ajar, dan bentuk penilaian, sedangkan integrasi dengan ekstrakurikuler dilakukan melalui beragam kegiatan sekolah. Prinsip pengembangan pendidikan karakter adalah mengintegrasikan secara komperhensif dalam kegiatan belajar. Oleh karena itu, kunci sukses pengembangan pendidikan karakter adalah guru harus: 1) merencanakan dan mengkreasi dokumen pendidikan karakter 2) mengajarkan nilai-nilai utama dalam mata pelajaran yang diampuh, 3) memberikan kesempatan kepada peserta didik mendiskusikan beragam isu moral dan karakter (Lickona, Schaps, dan Lewis, 2007).

Pemanfaatan bahan ajar dalam pembelajaran ilmu pengetahuan sosial bertujuan untuk meningkatkan pemahaman kondisi sosial yang ada di sekitar peserta didik sekaligus menanamkan nilai-nilai karakter bangsa yang menjadi tuntutan dari kurikulum. Mata Pelajaran ilmu pengetahuan sosial untuk jenjang pendidikan dasar dan menengah dicirikan dengan 1) mensistimatiskan 
bahan, informasi, dan kemampuan yang telah dimiliki tentang manusia dan lingkungannya menjadi bermakna, 2) lebih peka dan tanggap terhadap berbagai masalah sosial secara rasional dan bertanggungjawab, 3) mempertinggi rasa toleransi dan persaudaraan di lingkungan sendiri dan antar manusia (Freddy, 2018).

Bahan ajar ilmu pengetahuan sosial yang mengintegrasikan nilai pendidikan karakter memiliki urgensi untuk dikembangkan. Faktor yang melandasi kebutuhan bahan ajar ini adalah pada Kurikulum 2013 masih terus dibenahi dan bahan ajar yang relevan masih terbatas khususnya pada pendidikan khusus. Menurut Depdiknas (2008), penyusunan bahan ajar bertujuan 1) menyediakan bahan ajar yang sesuai dengan tuntutan kurikulum dengan mempertimbangkan kebutuhan peserta didik, yakni bahan ajar yang sesuai dengan dengan karakteristik dan latar atau lingkungan sosial peserta didik, 2) membantu peserta didik dalam memperoleh alternatif bahan ajar di samping bukubuku teks yang terkadang sulit diperoleh, dan 3) memudahkan guru dalam pembelajaran.

Bahan ajar ilmu pengetahuan sosial yang mengintegrasikan nilai karakter bangsa mengarahkan peserta didik untuk memahami beragam materi pembelajaran sekaligus untuk menanamkan pendidikan karakter. Kriteria pengembangan bahan ajar berbasis pendidikan karakter, yakni : 1) sesuai dengan kurikulum yang ditetapkan, 2) wacana yang digunakan sesuai dengan latar belakang peserta didik; 3) mengandung ilustrasi atau contoh yang memperjelas pemahaman; 4) mengandung pesan yang pantas bagi peserta didik, dan 5) mengandung unsur pendidikan, moral, atau nilai (Abidin, 2012)

Bahan ajar ilmu pengetahuan sosial yang dihasilkan dalam penelitian ini memiliki manfaat bagi guru dan peserta didik. Bahan ajar yang mengintegrasikan nilai karakter bangsa berfungsi; 1) sebagai panduan bagi guru yang akan mengarahkan aktivitasnya dalam proses pembelajaran, sekaligus merupakan substansi kompetensi yang seharusnya diajarkan kepada peserta didik: 2) sebagai pedoman bagi peserta didik yang akan mengarahkan semua aktivitasnya dalam proses pembelajaran, sekaligus merupakan substansi kompetansi yang seharusnya dipelajari/dikuasai Depdiknas (2008). “ Pengembangan bahan ajar didasarkan pada prinsip: 1) keterujian(validity): 2) kebermaknaan (significance) ;3) manfaat/kegunaan (utility): 4) kemungkinan untuk dipelajari (learnability); 5) kemenarikan (interest)" (Mulyasa, 2006, hlm, 154)

Model bahan ajar yang dikembangkan dalam penelitian ini adalah materi teks bacaan pada pembelajaran ilmu pengetahuan sosial yang disesuaikan dengan karakteristik anak tunarungu dalam memahami bahasa Indonesia dan diintegrasikan nilai-nilai karakter bangsa sesuai dengan materi atau pokok bahasannya.Penelitian ini bertujuan 
untuk menguji keefektifan bahan ajar ilmu pengetahuan sosial berbasis kurikulum 2013 yang mengintegrasikan karakter bangsa. Hasil penelitian diharapkan melengkapi referensi buku pelajaran tematik SDLB tunarungu berdasarkan Kurikulum 2013. Bahan ajar yang dihasilkan dioreintasikan menjadi bahan ajar pendamping dan bahan ajar pengayaan mata pelajaran ilmu pengetahuan sosial selain bahan ajar yang ditetapkan digunakan secara resmi oleh pemerintah.

\section{METODE}

Jenis penelitian ini adalah penelitian pengembangan (research and development). Penelitian didesain dengan model pengembangan Four-D Thiagarajan yang terdiri atas empat tahap, yaitu tahap pendefinisian (define), tahap perancangan (design), tahap pengembangan (develop), dan tahap penyebarluasan (dessiminate) (Thiagarajan, Semmel, dan Sammel, 1974). Dalam penelitian ini dikembangkan dua komponen, meliputi : bahan ajar dan perangkat pendukungnya. Bahan ajar dan perangkat pendukung yang dimaksud terdiri atas : Buku Siswa, lembar Kegiatan Siswa, Lembar Kegaiatan Siswa, Buku Guru, dan Rencana Pelaksanaan Pembelajaran (RPP).

Uji coba lapangan dilakukan dengan mengimplementasikan bahan ajar yang telah di desain. Kelas yang menjadi subyek uji coba adalah SDLB tunarungu kelas 4 dan kelas 5 SLB Pembina Tingkat Nasional Bagian C
Malang. Uji coba bertujuan menguji keefektifan bahan ajar yang dihasilkan. Pengumpulan data uji coba lapangan dilakukan melalui lembar observasi, angket, dan tes hasil belajar. Observasi dilakukan terhadap aktivitas peserta didik, pengelolaan pembelajaran guru, danketerlaksanaan bahan ajar. Pengamatan dilakukan untuk melihat aktivitas peserta didik yang meliputi: 1) mengikuti penyajian dengan seksama, 2) merespon penjelasan guru, 3) bertanya, 4) memberi umpan balik, 5) mengerjakan tugas, dan 6) melakukan aktivitas lain, seperti bermain. Angket respon guru kelas bertujuan untuk mengetahui tanggapan peserta didik terhadap model dan perangkat, meliputi : 1) Angket respon peserta didik terhadap penerapan bahan ajar untuk mendapat data (a) kesulitan peserta didik dalam menggunakan bahan ajar. (b) latihan yang disipkan, (c) nilai tambah yang dirasakan, dan, (d) saran perbaikan; 2)Angket respon peserta didik terhadap LKS : (a) bahasa, (b) penampilan, (c) sistematika, (d) manfaat, (e) kesesuaian, (f) alokasi waktu,(g) kesesuaian materi, dan (h) saran perbaikan ; 3) Angket respon peserta didik terhadap buku siswa untuk mendapat dat : (a) bahasa, (b) sistematis, (c) kepraktisan, (d) penampilan, dan (e) saran perbaikan. Tes hasil belajar bertujuan memperoleh data tentang tingkat penguasan peserta didik terhadap kompetensi yang diajarkan dan penggunaan bahan ajar.

Analisis data dilakukan untuk menilai keefektifan. Keefektifan bahan 
ajar ditentukan melalui analisis hasil belajar peserta didik. Langkah-langkah analisis hasil belajar dilakukan melalui prosedur penyekoran dan penentuan kreteria ketuntasan. Penyekoran dilakukan berdasarkan rambu-rambu jawaban yang telah ditetapkan. Penetapan ketuntasan belajar diukur berdasarkan katagori pencapaian kriteria ketuntasan belajar mata pelajaran yang ditetapkan dalam Kurikulum 2013. Skor hasil belajar peserta didik dihitung frekuensi dan persentasenta berdasarkan katagori penilaian disajikan pada Tabel 1.

Tabel 1. Kretiria Ketuntasan Hasil

Belajar

\begin{tabular}{|c|c|c|}
\hline Interval & Katagori & Keterangan \\
\hline $\begin{array}{ll}3,85 & - \\
4,00 & \end{array}$ & $\mathrm{~A}+$ & Tuntas \\
\hline $\begin{array}{ll}3,51 & - \\
3,84 & -\end{array}$ & A- & Tuntas \\
\hline $\begin{array}{ll}3,18 & - \\
3,50 & \end{array}$ & $\mathrm{~B}+$ & Tuntas \\
\hline $\begin{array}{ll}2,85 & - \\
3,17 & \end{array}$ & B & Tuntas \\
\hline $\begin{array}{ll}2,51 & - \\
2,84 & \end{array}$ & B - & Tuntas \\
\hline $\begin{array}{ll}2,18 & - \\
2,50 & \end{array}$ & $\mathrm{C}+$ & $\begin{array}{l}\text { Tidak } \\
\text { Tuntas }\end{array}$ \\
\hline $1,85-2,17$ & $\mathrm{C}$ & $\begin{array}{l}\text { Tidak } \\
\text { Tuntas } \\
\end{array}$ \\
\hline $\begin{array}{l}1,51 \\
1,84\end{array}$ & C - & $\begin{array}{l}\text { Tidak } \\
\text { Tuntas }\end{array}$ \\
\hline $\begin{array}{l}1,18 \\
1,50\end{array}$ & $\mathrm{D}+$ & $\begin{array}{l}\text { Tidak } \\
\text { Tuntas }\end{array}$ \\
\hline $\begin{array}{ll}1,00 & - \\
1,17 & \end{array}$ & D & $\begin{array}{l}\text { Tidak } \\
\text { Tuntas }\end{array}$ \\
\hline
\end{tabular}

Sumber : Permendikbud RI No 104/2014

\section{HASIL DAN PEMBAHASAN}

Hasil penelitian dipaparkan berdasarkan tahapan pengembangan yang dilakukan. Paparan hasil penelitian diuraikan sebagai berikut.

\section{Tahap Pendefinisian}

Kegiatan belajar dalam bahan ajar ditetapkan berdasarkan kompetensi dasar kurikulum 2013. Kegiatan pembelajaran yang dikembangkan adalah sebagai berikut: 1) menganalisis kebahasan cerita moral, 2) membedakan struktur cerita moral, 3) mengklasifikasi struktur cerita moral.

\section{Tahap Perancangan}

Produk utama yang dihasilkan dalam pengembangan bahan ajar adalah bahan ajar ilmu pengetahuan sosial yang mengintegrasikan nilai karakter berbasis kurikulum 2013. Struktur bahan ajar yang dihasilkan terdiri atas : 1) judul, 2) pengantar,3) pemahaman konsep, 4) pemodelan, 5) analisis teks, 6) integrasi nilai karakter. Bahan ajar ilmu pengetahuan sosial mencakup materi : 1) manusia, tempat dan lingkungan, 2) waktu, keberlanjutan , dan perubahan, 3) sistem sosial dan budaya. Cakupan materi tersebut di integrasi dengan nilai karakter. Bahan ajar diwujudkan dalam bentuk Buku Siswa dan Lembar Kerja Siswa yang dilengkapi dengan perangkat implementasi berbentuk Buku Guru dan RPP (Rencana Pelaksanaan Pembelajaran).

RPP (Rencana Pelaksanaan Pembelajaran) yang merupakan perangkat pendukung bahan ajar dikembangkan dengan mengacu kepada struktur RPP yang dikembangkan dengan 4 komponen 
utama yaitu : 1) identitas, 2) Tujuan pembelajaran, 3) langkah-langkah pembelajaran, dan 4) penilaian. Isi RPP dicirikan dengan pembelajaran berbasis teks dan integrasi nilai karakter. Lembar kerja siswa memuat kegiatan belajar yang mengarahkan kepada pencapaian kompetensi dasar. Struktur LKS terdiri atas : 1) judul, 2) identitas, 3) petunjuk, 4) wacana, dan 5) latihan.

\section{Tahap Pengembangan}

Kegiatan utama pada aspek pengembangan adalah validasi bahan ajar dan perangkat pembelajaran yang dilakukan oleh tim ahli.Validasi bertujuan untuk menilai kualitas bahan dan perangkat yang dikembangkan sekaligus memperoleh saran-saran perbaikan dan penyempurnaan produk. Penilaian mencakup aspek kelayakan isi, bahasa, sajian dan kegrafisan.

1. Hasil Pengembangan Rencana Pelaksanaan Pembelajaran Rencana Pelaksanaan Pembelajaran dikembangkan sesuai karakteristik kurikulum 2013.Validator memberikan penilaian terhadap 4 aspek utama RPP. Berdasarkan Tabel 2 RPP bahan ajar ilmu pengetahuan sosial yang mengintgrasikan pendidikan karakter berkatagori “ sangat baik"

Tabel 2. Hasil Validasi RPP

\begin{tabular}{|l|l|c|l|}
\hline No & \multicolumn{1}{|c|}{ Aspek } & $\begin{array}{c}\text { Rata- } \\
\text { rata }\end{array}$ & Katagori \\
\hline 1 & Identitas & 4,00 & $\begin{array}{l}\text { Sangat } \\
\text { Valid }\end{array}$ \\
\hline 2 & Tujuan & 3,67 & $\begin{array}{l}\text { Sangat } \\
\text { Valid }\end{array}$ \\
\hline 3 & $\begin{array}{l}\text { Langkah } \\
\text { Pembelajaran }\end{array}$ & 3,56 & $\begin{array}{l}\text { Sangat } \\
\text { Valid }\end{array}$ \\
\hline
\end{tabular}

\begin{tabular}{|c|c|c|c|}
\hline 4 & Evaluasi & 3,83 & $\begin{array}{l}\text { Sangat } \\
\text { Valid }\end{array}$ \\
\hline & Rata-rata & 3,76 & $\begin{array}{l}\text { Sangat } \\
\text { Valid }\end{array}$ \\
\hline
\end{tabular}

Setiap aspek yang telah divalidasi dinyatakan memenuhi kriteria kelayakan. Oleh karena itu produk RPP yang dihasilkan dapat digunakan untuk uji coba di lapangan.

2. Hasil Pengembangan Buku Guru.

Untuk menilai kelayakan Buku Guru validator memberikan penilaian terhadap emapat aspek, yakni: kelayakan isi, kelayakan penyajian, kelayakan bahas, dan kelayakan kegrafikan. Berdasarkan validasi ahli , buku guru yang dihasilkan berkatagori "sangat valid”. Rincian hasil validasi Buku Guru disajikan pada Tabel 3.

Tabel 3. Hasil validasi Buku Guru

\begin{tabular}{|l|l|l|l|}
\hline No & Aspek & $\begin{array}{l}\text { Rata- } \\
\text { rata }\end{array}$ & Katagori \\
\hline 1 & $\begin{array}{l}\text { Kelayakan } \\
\text { isi }\end{array}$ & 3,60 & $\begin{array}{l}\text { Sangat } \\
\text { Valid }\end{array}$ \\
\hline 2 & $\begin{array}{l}\text { Kelayakan } \\
\text { Penyajian }\end{array}$ & 3,42 & $\begin{array}{l}\text { Sangat } \\
\text { Valid }\end{array}$ \\
\hline 3 & $\begin{array}{l}\text { Kelayakan } \\
\text { Bahasa }\end{array}$ & 4,70 & $\begin{array}{l}\text { Sangat } \\
\text { Valid }\end{array}$ \\
\hline 4 & $\begin{array}{l}\text { Kelayakan } \\
\text { kegrafikan }\end{array}$ & 3,67 & $\begin{array}{l}\text { Sangat } \\
\text { Valid }\end{array}$ \\
\hline Rata-rata & 3,84 & $\begin{array}{l}\text { Sangat } \\
\text { Valid }\end{array}$ \\
\hline
\end{tabular}

Setiap subaspek Buku Guru yang divalidasi oleh ahli nyatakan telah memenuhi kriteria kelayakan.Oleh karena itu, Buku Guru dapat digunakan pada tahap uji coba lapangan. 
3. Hasil Pengembangan Buku Siswa

Untuk menilai Buku Siswa, validator memberikan penilaian terhadap empat aspek, yakni : kelayakan isi, kelayakan kebahasaan, kelayakan sajian, dan kelayakan kegrafisan. Berdasarkan hasil penilaian validator, Buku Siswa yang dikembangkan berkatagori "Sangat Valid”. Rincian hasil Validasi Buku siswa disajikan pada Tabel 4

Tabel 4 Hasil Validasi Buku Siswa

\begin{tabular}{|l|l|c|l|}
\hline No & \multicolumn{1}{|c|}{ Aspek } & $\begin{array}{c}\text { Rata- } \\
\text { rata }\end{array}$ & Katagori \\
\hline 1 & $\begin{array}{l}\text { Kelayakan } \\
\text { isi }\end{array}$ & 3,73 & $\begin{array}{l}\text { Sangat } \\
\text { Valid }\end{array}$ \\
\hline 2 & Kebahasaan & 3,80 & $\begin{array}{l}\text { Sangat } \\
\text { Valid }\end{array}$ \\
\hline 3 & Sajian & 4,83 & $\begin{array}{l}\text { Sangat } \\
\text { Valid }\end{array}$ \\
\hline 4 & Kegrafikan & 3,44 & $\begin{array}{l}\text { Sangat } \\
\text { Valid }\end{array}$ \\
\hline \multicolumn{2}{|c|}{ Rata-rata } & 3,70 & $\begin{array}{l}\text { Sangat } \\
\text { Valid }\end{array}$ \\
\hline
\end{tabular}

Setiap aspek penilaian Buku Siswa penilaian dinyatakan telah memenuhi kriteria kelayakan. Oleh karena itu Buku Siswa dapat digunakan untuk uji coba lapangan.

4. Hasil Pengembangan Lembar Kegiatan Siswa

Untuk menilai kelayakan Lembar Kerja Siswa (LKS) validator memberikan penilaian terhadap aspek yang terdiri atas : kelayakan isi, kebahasaan, sajian, dan kegrafisan. Berdasarkan hasil validasi ahli LKS yang dikembangkan berkatagori “
Sangat Valid” Rincian hasil validasi LKS disajikan pada Tabel 5.

Tabel 5 Hasil Validasi Lembar Kegiatan Siswa

\begin{tabular}{|l|l|c|l|}
\hline No & \multicolumn{1}{|c|}{ Aspek } & $\begin{array}{c}\text { Rata- } \\
\text { rata }\end{array}$ & Katagori \\
\hline 1 & $\begin{array}{l}\text { Kelayakan } \\
\text { isi }\end{array}$ & 3,73 & $\begin{array}{l}\text { Sangat } \\
\text { Valid }\end{array}$ \\
\hline 2 & Kebahasaan & 3,67 & $\begin{array}{l}\text { Sangat } \\
\text { Valid }\end{array}$ \\
\hline 3 & Sajian & 3,83 & $\begin{array}{l}\text { Sangat } \\
\text { Valid }\end{array}$ \\
\hline 4 & kegrafikan & 3,33 & $\begin{array}{l}\text { Sangat } \\
\text { Valid }\end{array}$ \\
\hline \multicolumn{2}{|c|}{ Rata-rata } & 3,64 & $\begin{array}{l}\text { Sangat } \\
\text { Valid }\end{array}$ \\
\hline
\end{tabular}

Setiap aspek LKS telah memenuhi kriteria kelaykan. Oleh karena itu LKS dapat digunakan pada tahap uji coba lapangan.

\section{Tahap Uji Lapangan.}

Paparan hasil penelitian yang berkaiatan dengan uji coba lapangan diuraikan sebagai berikut :

1. Respon peserta didik terhadap Buku Siswa

Analisis respon peserta didik terhadap Buku Siswa diukur melalui penggunaan bahasa, kejelasan konsep , penggunaan contoh, penyajian, kemenarikan. Analisis data respon peserta didik terhadap materi Buku Siswa menunjukkan bahwa setiap indikator memenuhi kriteria kelayakan. Rata-rata respon peserta didik untuk setiap aspek penilaian ditunjukkan pada Tabel 6 .

Tabel 6 Respon Peserta Didik terhadap Buku Siswa

\begin{tabular}{|c|c|c|c|}
\hline No & Aspek & $\begin{array}{c}\text { Rata- } \\
\text { rata }\end{array}$ & Katagori \\
\hline
\end{tabular}




\begin{tabular}{|l|l|c|l|}
\hline 1 & $\begin{array}{l}\text { Penggunaan } \\
\text { Bahasa }\end{array}$ & 3,23 & Tinggi \\
\hline 2 & $\begin{array}{l}\text { Kejelasan } \\
\text { Konsep }\end{array}$ & 3,25 & Tinggi \\
\hline 3 & $\begin{array}{l}\text { Penggunaan } \\
\text { contoh }\end{array}$ & 3,22 & Tinggi \\
\hline 4 & Penyajian & 3,26 & Tinggi \\
\hline 5 & Kemenarikan & 3,50 & $\begin{array}{l}\text { Sangat } \\
\text { Tinggi }\end{array}$ \\
\hline
\end{tabular}

Berdasarkan Tabel 6 di atas, setiap aspek penilaian Buku Siswa memperolah respons minimal berkatagori tinggi. Hasil tersebut menunjukkan bahwa bahan ajar yang di hasilkan memenuhi kriteria kelayakan.

2. Respon Peserta Didik terhadap LKS

Analisis respon peserta didik terhadap LKS diukur melalui indikator penggunaan bahasa, kemenarikan,fungsi memotivasi, kesesuaian gambar, alokasi waktu, dan kesesuaian dengan konsep pembelajaran.

Tabel 7 Respon Peserta Didik terhadap LKS

\begin{tabular}{|l|l|c|l|}
\hline No & \multicolumn{1}{|c|}{ Aspek } & $\begin{array}{c}\text { Rata- } \\
\text { rata }\end{array}$ & Katagori \\
\hline 1 & $\begin{array}{l}\text { Penggunaan } \\
\text { Bahasa }\end{array}$ & 3,20 & Tinggi \\
\hline 2 & Kemenarikan & 3,30 & Tinggi \\
\hline 3 & $\begin{array}{l}\text { Fungsi } \\
\text { motivasi }\end{array}$ & 3,22 & Tinggi \\
\hline 4 & $\begin{array}{l}\text { Kesesuaian } \\
\text { gambar }\end{array}$ & 3,26 & Tinggi \\
\hline
\end{tabular}

3. Analisis Hasil Belajar Peserta Didik
Keefektifan bahan ajar diukurberdasarkan hasil belajar peserta didik yang diperoleh melalui tes. Analisis hasil belajar peerta didik menunjukkan bahwa bahan ajar efektif digunakan untuk mencapai kompetensi dasar.

\section{PENUTUP}

Berdasarkan hasil uji lapangan yang telah dilakukan disimpulkan bahwa beberapa hal sebagai berikut 1) Respon peserta didik terhadap bahan ajar, meliputi Buku Siswa dan LKS serta proses pembelajaran menunjukkan bahwa bahan ajar yang diuji cobakan telah memenuhi kriteria. 2) Penerapan bahan ajar yang diukur melalui analisis keterlaksanaan bahan ajar bahwa bahan ajar praktis digunakan dalam proses pembelajaran. 3) Prestasi belajar yang diperoleh peserta didik melalui penerapan bahan ajar telah memenuhi keefektifan. Secara umun, peserta didik telah memenuhi kriteria ketuntasan minimal. 4) berdasarkan pelaksanaan uji lapangan dilakukan beberapa revisi ringan terhadap bahan dan perangkat.

\section{DAFTAR PUSTAKA}

Abidin, Y. (2012). Pembelajaran Membaca Berbasis Pendidikan Karakter. Bandung: Refika Aditama.

Depdiknas. (2008). Panduan Pengembangan Bahan Ajar. Jakarta: Depdiknas 
Drake, S.M, and Burns, R.C. (2004). Meeting Standards Through Integrating Curriculum. Virgin: ASCD.

Ariesta, Freddywidya. (2018). Karakteristik IPS di Sekolah Dasar. Artikel 8 Januari 2018.

Kasim, M.2012. Sosialisasi Kurikulum 2013 di Sulawesi Selatan. Makssar 8-9 Februari 2013

Larson, K. (2009). Understanding the Importance of Character Education. Tesis. Wisconsin: The Garaduate Schol University of WisconsinStout.

Lickhona, T. (2008). Educating for Character. New York Bantan Book

Lickhona, T, Schaps,E, and Lewis, C. (2007). Principles of Effective Character Education .Washington: Character Education Partnership.
Mulyasa, E.(2006). Kurikulum yang Disempurnakan Pengembangan Standar Kompetensi dan Kompetensi Dasar. Bandung: Remaja Rosda.

Sultan, Muhammad Saleh. (2015). Pengembangan Bahan ajar Bahasa Indonesia Berbasis Kurikulum 2013 yang Mengintegrasikan Nilai Karakter Bangsa di SMP.Jurnal

UniversitasMalang:117-129.

Narvaez D. and Daniel, K.L. (2008). Teaching Moral Character:Two Alternatives for Teaching Education. The Teacher Educator, 43(2):156172.

Thiagarajan, S, Sammel, D.S, and Sammel,M.I. (1974). Instructional Development for Training Teachers of Exceptional Children. Indiana: Indiana University. 